\title{
Factors Affecting the Improvement of District Heating. Case Studies of Estonia and Serbia
}

\author{
Pavel RUŠELJUK ${ }^{1}$, Anna VOLKOVA ${ }^{2 *}$, Nebojša LUKIĆ ${ }^{3}$, Kertu LEPIKSAAR $^{4}$, \\ Novak NIKOLIĆ ${ }^{5}$, Aleksandar NEŠOVIĆ ${ }^{6}$, Andres SIIRDE ${ }^{7}$ \\ 1, 2, 4, 7 Tallinn University of Technology, Ehitajate tee 5, 12616 Tallinn, Estonia \\ ${ }^{1}$ Eesti Energia Narva Soojusvõrk, Oru 2, 20203 Narva, Estonia \\ 3, 5, 6 University of Kragujevac, Jovana Cvijića 6б, Kragujevac 34000, Serbia
}

\begin{abstract}
Factors affecting both the Estonian and Serbian district heating improvement are analysed, including geographical and climate factors, as well as economic and legal factors. This analysis is added by evaluation of main technical and economic parameters related to the district heating networks from the case studies (Estonian Narva city and Serbian Kragujevac district heating). This analysis uncovered the weakest points of Kragujevac district heating and explain why district heating is not considered as sustainable and environmentally friendly heating option.
\end{abstract}

Keywords - Biomass; district heating; district heating network; fossil fuel; pipes; renewable energy

\section{INTRODUCTION}

District heating $(\mathrm{DH})$ can be considered the optimal/most preferable option only when heat production, transmission, and consumption is energy-efficient, competitive, and environmentally friendly [1].

Many studies have analysed the factors affecting DH. In [2], a method was proposed for describing the factors that affect energy systems. According to [2], there are several sets of technical and economic factors: energy sources, design considerations, environmental impact, performance analysis, and energy policy. It is also necessary to determine the necessary improvements to the system [1]. In [2], a different approach was proposed where key technical and economic factors were divided into three major groups: fuel-related factors, network factors, and energy production factors [3]. The factors related to fuel include fuel costs, environmental scenarios, existing fuel supply infrastructures, transportation and storage logistics, energy density, and fuel quality [2]. The factors associated with the DH network are heating load, energy efficiency of buildings and costs of DH pipeline installation/refurbishment. The factors that affect energy production are the selling price and subsidies.

To determine the importance of a factor, an assessment matrix can be built. In [4], an assessment matrix of 31 parameters was created and used to assess future DH challenges in the case of Austria for various future scenarios. The indicators in this assessment were heat consumption density, full load hours, available heat sources and temperature.

* Corresponding author.

E-mail address: anna.volkova@taltech.ee 
In [5], a method was proposed for assessing the current state of DH and its development potential. This assessment is necessary to prevent stagnation in the $\mathrm{DH}$ sector. Technical factors include heating load, length of pipes, heating used in buildings, as well as degree days. Among the most important economic factors is the DH market share. According to [5], the most important factor is the heating load.

Technical factors that affect the DH improvement potential are described in [6]. To evaluate the current technical condition of the DH network, the following parameters should be taken into account: the duration of the heating season, average monthly ambient temperature, as well as temperature graphs showing the dependence of the supply and return temperatures on the ambient temperature. When considering these parameters, one can estimate the overall heat transfer coefficient of a DH network. To assess the DH network's improvement potential, an important factor to consider is friction loss, which depends on pipeline geometry, pipeline length, differential pressure necessary for boiler room operation, the amount of electricity used for pumping, heat loss due to pipe diameter and pipeline heating load.

Energy policy is another important factor affecting the DH sector, in addition to technical and economic factors. Energy policy measures, such as the tariff system and support policies, also affect DH. The economic feasibility of various development scenarios was studied in [7], and it was determined that for DH prosumers to continue investing in future developments, the DH tariff cannot be reduced. An appropriate tariff system can encourage DH prosumers to increase the efficiency and use of renewable energy sources [8].

DH support measures can also act as burden measures, market control or financial support [9]. Carbon taxes on fossil fuels are a good example of a burden measure. Financial support can be provided through grants for investments in initiatives related to expansion, efficiency and environmental improvements.

Legislation is also important in maintaining DH feasibility [10]. Legislation must consider the market situation to be able to promote DH in the country. In general, the market situation can be divided into 4 stages: consolidation, refurbishment, expansion and new development, as stated in [10].

DH is also affected by primary energy factors (PEF) due to Directive 2010/31/EU of the European Parliament and of the Council of 19 May 2010 on the energy performance of buildings [11], which states that the number of nearly zero-energy buildings must increase and to achieve this, PEFs are introduced to determine the energy consumption of the building. [12] examined PEFs for DH in different EU member states. In [13], a methodology was proposed for evaluating PEF for energy-efficient $\mathrm{DH}$.

\section{Factors AfFecting District Heating Development}

As can be seen from the previous review, many factors affect the implementation and further development of district heating. DH implementation is usually associated with factors such as climate conditions and building density.

Climate conditions influence the district heating sector, which is confirmed by the fact that the most developed DH networks are in countries with colder climates [10], for example, in Sweden [14], Finland [15], Estonia [16], and Latvia [17]. On the other hand, there are countries with cold climates, such as Norway, the UK and the Netherlands, where the share of DH is not very high, which can be explained by the influence of other factors [11].

Another factor is the building sector. In the case when the building density is high and the proportion of multi-family apartment buildings is also high, this leads to a greater heat load, which is significant for district heating feasibility and sustainability. 
DH should be a competitive heating option. If other heating options are more available and affordable, this can lead to a low share of DH. For example, in Norway, where electricity is cheap and widely available, the share of DH is about $12 \%$ [18]. However, low-temperature DH can also be implemented in Norway. Possible development and transition towards lowtemperature DH in Norway using various technical solutions, including large heat pumps, is discussed in [17].

Political factors, such as support measures and legislation changes have been analysed in various studies. However, in addition to these factors, there are other important external political processes/changes that have a big impact on improving $\mathrm{DH}$.

For example, the high share of DH in the countries of the former Eastern Bloc is due to the fact that during the 1960s and 1970s cities were transformed via mass housing development projects, which included the development of DH networks. The urban infrastructure appeared as a result of rapid industrial expansion, urbanisation, and modernisation, supported by the socialist self-management system [19].

Other political processes, such as the independence of the Baltic countries, have led to a complete restructuring of the infrastructure, including DH. The decline of socialism has led to the transformation of property ownership, both for residential buildings, heat production units, and DH networks. Other changes, such as closing of industry and industrial enterprises that were either heat providers or consumers have had an impact on district heating. For example, the Krenholm Manufacturing Company (Narva, Estonia), one of the main consumers of steam produced by the Balti Power Plant in the second half of 2000, installed its own gas boiler.

Another problem faced during this period was an opportunity for buildings to disconnect from the DH network, thus reducing the district's heating load. In 2000, the two largest apartment buildings in Narva (700 apartments) refused DH installing gas boiler instead, and only in 2012 they returned to DH.

The same political processes influenced the availability of fuel used for DH. Fuel that used to be cheap and widely available before these political events was no longer as affordable. Higher prices for imported fuels caused a switch to local fuels, such as shale oil and wood in the case of Estonia.

In the case of Serbia, the key political events that affected the energy sector include the Yugoslav Wars and the breakup of Yugoslavia. For example, in Kragujevac during the war, a power plant that provided the city with heat was bombed and sustained serious damage. Industry closure occurred, and in some cities, such as in Kragujevac, heat production must be completely changed. For example, after 2000, most of the Zastava factory complex was closed, and the share of industrial energy needs fell below $10 \%$ of the total Energetika (Kragujevac energy company) energy production. Since then, DH has become the goal of the Energetika Company. During this transition period, the network and heat production were in poor condition.

20 years ago, the situation with DH was almost the same in both Serbia and Estonia. But if we look at the DH sector now, we can tell that DH in Estonia is rapidly developing and numerous efforts are being made to transition towards the 4th generation DH. The DH sector in Serbia is also developing, but not as fast, and there are various specific barriers, both past and present, that do not allow DH to improve. These factors will be analysed in this paper. Two DHNs were selected for a more detailed analysis. Serbia's Kragujevac DHN will be compared with Estonia's Narva DHN. The annual heat consumption in Kragujevac is proportional to the heat consumption in Narva. 
Existing problems, as well as measures aimed at improving DH, will be analysed and DH improvement scenarios will be developed based on this analysis.

\section{Evaluation Methodology}

The comparative methodology will include two sections. The first section will be related to the factors that affect both the Estonian and Serbian district heating sectors. Based on the literature review, the following key factors will be analysed and compared for Estonia and Serbia: geographical and climate factors, as well as economic and legal factors.

Geographical and climate conditions: as mentioned above, this group of factors has an impact on DH implementation and improvement. Geographical conditions associated with $\mathrm{DH}$ include the average outdoor temperature and the length of the heating season.

Another aspect related to geographical conditions is resource availability. The following resources need to be analysed: fossil fuel availability and renewable energy availability. In addition, all available heating options, such as electric heating, should also be analysed.

Economic and legal factors will be reflected in an analysis of the available government support instruments, such as supporting regulations, taxes, special loan conditions, etc. In addition, economic and legal factors will also be covered in an analysis of fuel prices, operating costs and the tariff system.

External social and political processes and their impact on DH will also be evaluated.

The second section of the analysis will include a set of the main technical and economic parameters related to the $\mathrm{DH}$ networks from the case studies.

The analysis of technical parameters will include the following steps: a brief description of the network and its improvement over the past 20 years, as well as the calculation of such parameters as the number of consumers, the amount of fuel used, $\mathrm{CO}_{2}$ emissions, the share of DH in the city, etc.

Each city has a different way of calculating tariffs, therefore, for comparison, the recalculated tariffs (EUR/MWh) will be taken from the analysis conducted in [19]. The tariffs will be compared with other heating options in the region.

This analysis will uncover the weakest points and explain why DH is not considered a sustainable and environmentally friendly heating option. Based on this analysis, recommendations will be made for Kragujevac DH.

It should be added that the comparison of the two DH networks was limited by the availability of data from the Kragujevac DH systems. This can be explained by the fact that not all data was collected or provided by the operator. In addition, there is remote metering data available for Narva, but none is available for Kragujevac, so this type of data could not be used in the analysis.

\section{District Heating in Estonia AND Serbia}

\subsection{Climate factors}

When comparing district heating in Estonia and in Serbia, it should be noted that the climate in Serbia is warmer than in Estonia.

For example, changes in outdoor temperature for Narva (Estonia) and Kragujevac (Serbia) are shown in Fig. 1., 1 and as it can be seen, daily average outdoor temperature in Kragujevac is higher during all the year comparing to outdoor temperature in Narva. 


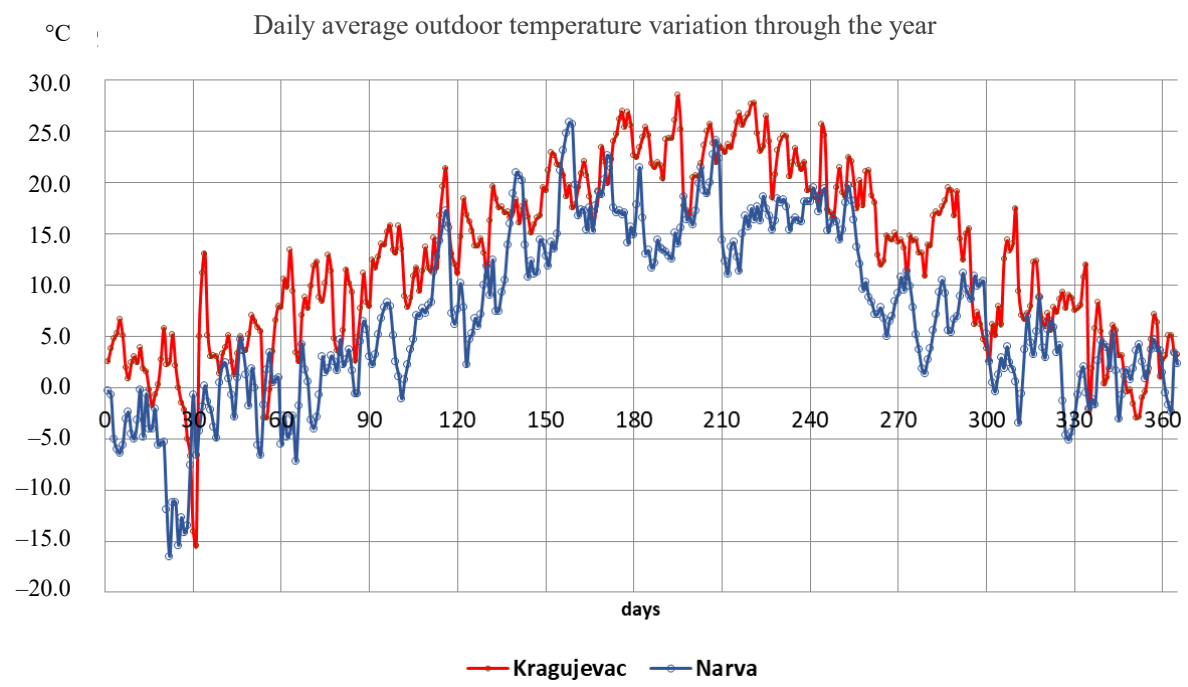

Fig. 1. Average daily outdoor temperatures for Narva and Kragujevac.

\subsection{Availability of local resources}

The energy resources used for DH can be seen in Fig. 2 (a) and (b) for both countries starting in 2010 .

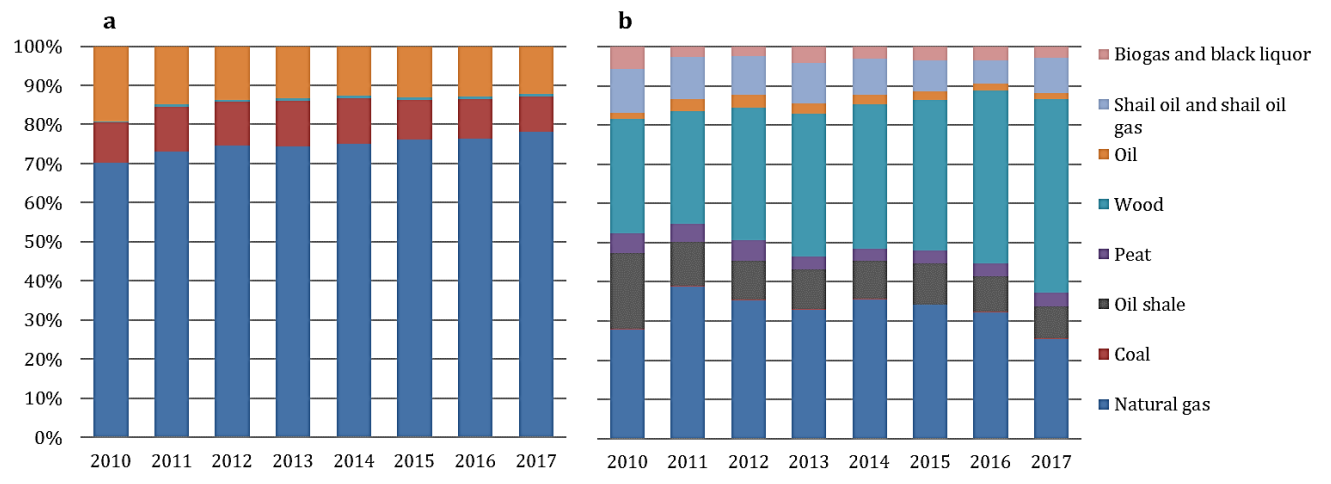

Fig. 2. Fuel consumption for DH in Serbia (a) and Estonia (b).

In Serbia, the share of natural gas is increasing every year. Coal is also used for heating, but the amount of wood consumed is very small. 20 years ago, boiler plants mainly used coal and fuel oil to produce thermal energy. Today, the share of such boiler plants has decreased significantly, because more and more boilers are switching to natural gas, which is also mandatory for new boiler plants.

As can be seen in Estonia, the use of oil and natural gas has been on the decline since 2010. The use of wood for heating has increased, which can be explained by strong government support. Additionally, it should be explained why the use of shale oil and shale oil gas has 
increased. This is due to increasing production of shale oil, where shale oil gas is considered a by-product and is used for DH.

20 years ago, the share of heavy oil-based boilers was rather high in Estonia. But it has been decreasing every year due to the high price of heavy oil and environmental regulations. This amount reflects available capacities, but oil-based boilers are mainly used as backup boilers.

Coal is the local fuel in Serbia, and oil shale is the local fuel in Estonia. These fuels are fossil fuels, but their price can compete with imported fuels, so these fuels (or products made from these fuels) are used for $\mathrm{DH}$.

Biomass availability is higher in Estonia. In [21], the available mass of these types of biofuels is estimated for various EU countries. As a result, it was determined that in Estonia the available agricultural residue is about 1.1 million tons per year, forestry residue is about 0.99 million tons per year, and available biological waste is about 0.11 million tons per year. [22] also assessed the potential of woody biomass from forests, including stemwood, logging residues, and stumps, in EU countries. According to [22], Estonia is among the regions with the highest biomass availability, where the available biomass per hectare is between $0.51-$ 0.75 tons per year. The share of forests in the total land area in Estonia is $51.4 \%$, of which $74 \%$ are profitable forests and $26 \%$ are nature reserves, according to Estonian Statistics [23]. As for biomass availability in Serbia, the total Serbian biomass energy potential can be estimated at 2.5 to $3 \mathrm{Mt}$, of which $40 \%$ is wood biomass and $60 \%$ is agricultural biomass.

Another renewable energy source is geothermal energy. Current studies show that in Estonia there is no potential for using geothermal energy for DH. In Serbia, the total Serbian energy potential of geothermal energy can be estimated at $320 \mathrm{MW}$. These are mainly lowtemperature sources $\left(20-100^{\circ} \mathrm{C}\right)$, suitable for use as heating energy or for heat pump use.

Solar energy in Estonia is mainly used for electricity production. According to [24], in $2018,13 \mathrm{GWh}$ of solar electricity was produced, which is $0.8 \%$ of the total RES electricity and $0.13 \%$ of the total electricity production. Solar energy is not used as thermal energy in the DH sector in Estonia. And in Serbia, the total potential of solar thermal energy can be estimated at 10 million $\mathrm{m}^{2}$ of installed solar collectors and $7000 \mathrm{GWh}$ thermal energy per year [25]. Due to the lack of significant government subsidies and low electricity prices, the assessment of the potential of solar energy in Serbia is only theoretical. As for solar heat, this assessment is mainly for individual heating and only a small fraction of the heat load can be covered by central solar heating.

It should also be noted that in terms of local resources, cheap electricity is available for heating in Serbia. The low price of electricity is determined by factors, such as available coal resources that are used for electricity generation, as well as hydro sources.

\subsection{Prices of energy resources}

Energy prices are very important for analysing the competitiveness of DH. On the one hand, fuel prices affect heating tariffs; on the other hand, a low price of natural gas, for example, can lead to a switch from DH to gas heating. Cheap electricity will cause consumers to choose electric heating over $\mathrm{DH}$.

The price of heating for consumers is lower than the cost of electricity in Estonia. As mentioned earlier, the price of electricity in Serbia is very low, which can be explained by the availability of coal and hydropower resources. Other factors include the lack of $\mathrm{SO}_{2}$ and $\mathrm{NO}_{\mathrm{x}}$ control and $\mathrm{CO}_{2}$ penalties.

Often, Estonia is portrayed as a great example of a centrally controlled district heating market subject to a consistent set of regulations, where the roles and obligations of different 
parties are clear and reasonable. The history of the regulation and its fundamental characteristics can be found below [26].

Until 1998, municipalities carried out mild price regulation. In 1998, the Energy Act introduced ex-ante pricing for DH grids and heat-only boilers that is set on a case-by-case basis by the new national regulatory authority (the Energy Market Inspectorate at the time) as the maximum price for end users (DH price cap). The price of heat for end users is determined by the national regulatory authority in order to cover the costs of the DH company and receive a reasonable return (regulatory WACC), which is calculated today according to the methodology publicly available on the Estonian Competition Authority (ECA) website.

Estonian DH market is regulated by the District Heating Act (DHA) and the Competition Act; the maximum prices charged in network regions have to be approved by the Competition Authority. The DHA regulates the activities related to the production, distribution and sale of heat through DH networks and connection to said networks. The DHA entered into force in February 2003 and has been amended a number of times since. This requires heating companies to maintain separate accounts for the production, distribution and sale of heat, and other activities, as well as for the costs incurred in combined heat and power (CHP) plants. The DHA also stipulates that the price of heat produced in CHP processes is subject to approval by the Competition Authority. The task of the Competition Authority is to coordinate prices of DH in such a way as to avoid cross-subsidisation of electricity in the allocation of costs. Based on the DHA, heating companies can apply to the Competition Authority for approval of a price formula for a period of up to three years. This price formula is used if factors that are beyond its control and which affect the price of heat become evident [27].

The DHA, which was in force until 2010, did not foster competition or regulate market access for new producers. Since heat production and distribution networks are often owned by the same companies enjoying monopoly power, new heat producers have no alternative but to sell heat to the existing heating network.

At the beginning of 2020 , the weighted average value of the maximum $\mathrm{DH}$ prices is $60 \mathrm{EUR} / \mathrm{MWh}$; the lowest price is $35 \mathrm{EUR} / \mathrm{MWh}$ (excluding $20 \% \mathrm{VAT}$ ), and the highest price is $86 \mathrm{EUR} / \mathrm{MWh}$. As a rule, the actual selling price is very close to the defined maximum price. The procedure or methodology for coordinating the maximum price was developed by the Competition Authority, and since November 2010, all DH providers must request coordination of their maximum prices from the Competition Authority.

Table 1. District Heating Prices in Kragujevac [29]

\begin{tabular}{llll}
\hline \multicolumn{4}{c}{ Pausal payment } \\
\hline Consumer & Fixed, & Variable, & Total, \\
category & $€ / \mathrm{m}^{2}$ & $€ / \mathrm{m}^{2}$ & 0.71 \\
\hline Housing & 0.23 & 0.49 & 1.07 \\
Social activities & 0.34 & 1.47 & 2.14 \\
Other users & 0.68 & Variable, & \\
\hline & Payment by consumption & \\
\hline Consumer & Fixed, & $€ / \mathrm{MWh}$ & \\
category & $€ / \mathrm{m}^{2}$ & 41.89 & \\
\hline Housing & 0.23 & 62.84 & \\
Social activities & 0.34 & 62.84 & \\
Other users & 0.68 & & \\
\hline
\end{tabular}


The price of heat delivered to the DH system in the Republic of Serbia is regulated by local authorities in accordance with the established methodology [27], therefore it differs from city to city. The prices of DH for the city of Kragujevac are shown in Table 1.

\subsection{Emissions}

In accordance with the Kyoto Protocol, Estonia started selling Assigned Amount Units (AAUs) in 2009 as part of the Green Investment Scheme (GIS) and has earmarked the proceeds for projects that facilitate emission reduction. Examples include wind farms, CHP plants, improving DH networks, retrofitting boiler houses, improving energy efficiency in buildings and industries, as well as introducing more efficient buses, trams and electric vehicles. Under EU law, Estonia is obliged to limit the growth of GHG emissions from outside the EU-ETS sector to $11 \%$ between 2005 and 2020 [3].

$\mathrm{A} \mathrm{CO}_{2}$ pollution charge applies to heat producers in the DH system. Since 2009 , the rate has been 2 EUR per ton. Electricity producers also used to be subject to a pollution charge, but since January 2008 they are subject to an excise tax. The latest tax has been 4.47 EUR/MWh since March 1, 2013.

Serbia committed to and signed the Paris Agreement on Climate Change in April 2016 and ratified it in July 2017, pledging to cut $9.8 \%$ of $\mathrm{CO}_{2}$ emissions by 2030 . This is a rather ambitious task. According to earlier forecasts, electricity producers will be faced with an obligation to pay for $\mathrm{CO}_{2}$ in Serbia between 2020-2025, when the country is expected to join the EU [29]. Emission allowances are not implemented in Serbia. The reason is that such a measure could lead to an increase in the price of other energy sources, including electricity, the price of which in Serbia is one of the lowest in Europe. However, to further European integration, Serbia is obliged to introduce this measure at some point. The first step has already been taken at the end of 2019 when a tender was announced to prepare a study on the introduction of the $\mathrm{CO}_{2}$ tax. The tender was held by the Energy Community with the ultimate goal of preserving the environment.

\subsection{Financial support}

The Environmental Investments Centre (EIC) was founded in Estonia in 2000, and it has been one of the main sponsors of environmental projects in Estonia over the past 20 years. In 2009, the EIC (KIK in Estonian) awarded grants to local governments, non-profit associations, businesses and foundations as part of the 'Broader use of RES for energy generation' programme that used funding from the European Regional Development Fund (ERDF). The state provides support to the heating sector mainly through environmental protection and regional development goals. From 2005 to 2009, the heating sector received EUR 13.9 million from the ERDF and Estonian environmental taxes, as well as EUR 0.9 million from the state budget and through the support scheme for investments in energysaving solutions during the same period.

The 2009 application round had a total funding volume of approximately EUR 9.6 million and 17 projects received grants for the reconstruction of boiler houses, DH networks and construction of CHP plants in accordance with the support mechanism for the generation of electricity in cogeneration and from renewable sources.

The EIC manages a national programme called 'Extended use of renewable energy sources (RES) for energy generation and reconstruction of DH networks', which is funded by $\mathrm{CO}_{2}$ quota sales. It supports three types of activities: construction of CHP plants that use RES; 
reconstruction of boiler houses; reconstruction of $\mathrm{DH}$ networks to reduce thermal transmission losses.

In 2014-2020, the grant is allocated from the measure 'Effective Production and Transmission of Thermal Energy' for structural aid. The total budget of the application round is EUR 18 million. Of these, EUR 12 million are planned for boiler renovations. EUR 6 million has been allocated for the repair of heating pipelines, the construction of new connections and a new DH system. The grant is funded by the European Union Cohesion Fund.

In Serbia, financial support for DH is sporadic. Starting from 2001 investments for infrastructure have been provided by the European Bank for Reconstruction and Development. One of the biggest projects was supported by KfW Development Bank [30]. As a result of this support, $42 \mathrm{~km}$ of pipes were restored in 18 cities, 7 new boilers were installed, 2 boilers were renovated, 1 CHP was installed, pump stations were renovated, 1000 remote meters and 500 substations were installed. It is evident that this support is not regular and there is no continuing support from the government, and the improvement of DH is still very slow.

\subsection{Additional support}

In 2004, the District Heating Act entered into force in Estonia, allowing municipalities to create DH zones where DH is the only option for heat supply, with the exception of non-fuel (i.e., heat pumps) or renewable energy sources. However, this Act does not provide a methodology or criteria for creating a DH zone, leaving it up to municipalities. In 2010, the DH Act was amended to establish the ECA as the DH regulator, as well as third-party access rules. These rules consist mainly of the obligation of $\mathrm{DH}$ operators to organise a tender for new generation capacity, where tender documentation must be approved by the ECA.

Based on this analysis, factors affecting DH at the national level are presented in Table 2.

Additionally, a comparison of the Kragujevac and Narva DH systems is presented in Table 3.

Previously, the Kragujevac DH system had significant losses of water in the pipes due to water treatment capacities and, consequently, oxidation inside the pipes and its degradation. With the help of the EU loans, new pre-insulated pipes were partially implemented (to some per cent), and new combined (gas and oil) hot water boilers were installed instead of inefficient coal boilers.

25 years ago, the entire city of Narva was centrally supplied with heat through the Balti Power Plant, and domestic hot water (DHW) was supplied through a mixing valve system. Almost all heating units used a mixing valve system, and the DHW system was open. In 1996-1997, the city implemented a programme to replace mixing valve heating units in houses. 270 automated heating units were installed, and the domestic hot water system was rerouted into an independent circuit. Over the past 20 years, quite a few new DH consumers have been added to the system. 
TABLE 2. ANALYSIS OF FACTORS AFFECTING DH SYSTEMS

\begin{tabular}{|c|c|c|c|}
\hline Factor & Estonia & Serbia & Impact on DH development. \\
\hline Climate factors & Cold climate & Warmer climate & $\begin{array}{l}\text { In warmer climates, annual heat } \\
\text { consumption and peak heat load are lower. } \\
\text { DH improvement does not always have high } \\
\text { feasibility. In warmer climates, heat loss is } \\
\text { lower, while distribution efficiency is } \\
\text { higher. }\end{array}$ \\
\hline Local fossil fuels & Oil shale, Shale oil & Coal & $\begin{array}{l}\text { When local fossil fuels are available and at } \\
\text { lower prices, it is more difficult to } \\
\text { implement renewable energy sources for } \\
\text { heat production. }\end{array}$ \\
\hline $\begin{array}{l}\text { Renewable energy } \\
\text { availability }\end{array}$ & $\begin{array}{l}\text { Biomass availability } \\
\text { is high. Wood chips } \\
\text { are available in } \\
\text { sufficient quantities. }\end{array}$ & $\begin{array}{l}\text { Biomass } \\
\text { availability is } \\
\text { lower, but still } \\
\text { available, as well } \\
\text { as geothermal } \\
\text { energy. }\end{array}$ & $\begin{array}{l}\text { Biomass availability allows to produce heat } \\
\text { from renewable energy sources }\end{array}$ \\
\hline $\begin{array}{l}\text { Legislative and } \\
\text { regulatory } \\
\text { instruments }\end{array}$ & $\begin{array}{l}\text { Electricity market } \\
\text { act: feed-in premium } \\
\text { tariffs for biomass } \\
\text { CHP }\end{array}$ & $\begin{array}{l}\text { National plans to } \\
\text { increase the share } \\
\text { of renewable } \\
\text { energy }\end{array}$ & $\begin{array}{l}\text { Specific support mechanisms introduced in } \\
2007 \text { over the course of several years led to } \\
\text { an increase in renewable electricity in } \\
\text { Estonia from } 2 \% \text { to } 15 \% \text { due to the } \\
\text { installation of a new biomass CHP. Only } \\
\text { clear and consistent support mechanisms } \\
\text { with a long-term perspective have an impact } \\
\text { on DH. }\end{array}$ \\
\hline Emission regulations & $\mathrm{CO}_{2}$ emission taxes & $\begin{array}{l}\text { Only planned, no } \\
\text { restrictions }\end{array}$ & $\begin{array}{l}\text { There are no financial benefits in Serbia to } \\
\text { replace fossil fuels with renewable energy. } \\
\text { The renovation is mainly focused on } \\
\text { replacing coal boilers with gas boilers. }\end{array}$ \\
\hline $\begin{array}{l}\text { District heating } \\
\text { regulations }\end{array}$ & $\begin{array}{l}\text { District heating act: } \\
\text { DH regions }\end{array}$ & $\begin{array}{l}\text { No specific DH } \\
\text { regulations }\end{array}$ & $\begin{array}{l}\text { Estonian DH operators have guarantees that } \\
\text { there will be heat consumers in the future. }\end{array}$ \\
\hline Tariff system & $\begin{array}{l}\text { Tariff stimulates } \\
\text { system improvement }\end{array}$ & $\begin{array}{l}\text { Every authority } \\
\text { has its own tariff } \\
\text { system. }\end{array}$ & $\begin{array}{l}\text { DH tariffs are competitive with other } \\
\text { heating options }\end{array}$ \\
\hline $\begin{array}{l}\text { Prices compared to } \\
\text { other fuels, } \\
\text { electricity, etc. }\end{array}$ & Competitive or lower & $\begin{array}{l}\text { Higher than other } \\
\text { options }\end{array}$ & $\begin{array}{l}\text { In Serbia, consumers often prefer other } \\
\text { heating options. }\end{array}$ \\
\hline
\end{tabular}

Unfortunately, it was not possible to obtain the necessary data from the DH company because this data was not collected or not provided. Even heat losses could not be compared. That is why it is rather difficult to compare the two systems. Smaller number of substations in Narva can be explained by colder climate and higher heat consumption per each substation. Another factor is that 9-floor large multifamily buildings are the main DH consumers in Narva city, and in Kragujevac smaller 3-5 floor buildings are more typical, as DH consumers. Larger number of employees in Kragujevac can be explained by the fact, that the DH company employs production, distribution and repair workers, but in Narva DH company employs only production and distribution workers. 
TABLE 3. COMPARING OF KRAGUJEVAC AND NARVA DH SYSTEMS

\begin{tabular}{|c|c|c|}
\hline Parameter & Kragujevac & Narva \\
\hline Total nominal installed capacity & 432.65 MW & $\begin{array}{l}160 \mathrm{MW} \text { (Power plant) }+ \\
240 \mathrm{MW} \text { (gas boiler house) }= \\
400 \mathrm{MW}\end{array}$ \\
\hline Heat generation units & $\begin{array}{l}\text { coal boilers } \\
\text { heavy oil/gas boilers }\end{array}$ & $\begin{array}{l}\text { oil-shale/biomass power plant } \\
\text { natural gas boilers }\end{array}$ \\
\hline Heat production (2017) & $385000 \mathrm{MWh}$ & $389000 \mathrm{MWh}$ \\
\hline Fuel & $\begin{array}{l}63 \% \text { coal, } \\
24 \% \text { heavy oil } \\
13 \% \text { natural gas }\end{array}$ & $\begin{array}{l}49 \% \text { Oil shale, } 1 \% \text { Shale oil, } \\
25 \% \text { biomass } \\
25 \% \text { natural gas }\end{array}$ \\
\hline $\mathrm{CO}_{2}$ per $\mathrm{MWh}$ produced & $0.39 \mathrm{tCO}_{2} / \mathrm{MWh}$ & $0.26 \mathrm{tCO}_{2} / \mathrm{MWh}$ \\
\hline Share of remote metering & $0 \%$ & $99 \%$ \\
\hline Number of separate DH districts & 3 & 1 \\
\hline Tariff (for a $50 \mathrm{~m}^{2}$ apartment) per MWh & $\begin{array}{l}\text { 28.4 Euro/MWh for fix and } 59.5 \\
\text { Euro/MWh for variable tariff }\end{array}$ & 35.33 Euro/MWh \\
\hline $\begin{array}{l}\text { Tariff compared to electric heating } \\
\text { DH tariff/Electricity tariff }\end{array}$ & $\begin{array}{l}28.4 / 70=0.41 \text { and } \\
59.5 / 70=0.85\end{array}$ & 0.36 \\
\hline Number of employees & 300 & 50 \\
\hline Total number of substations & 2095 & 724 \\
\hline Total length of heating pipes & $81 \mathrm{~km}$ & $77 \mathrm{~km}$ \\
\hline Key issues & $\begin{array}{l}\text { Water leakage } \\
\text { Low efficiency } \\
\text { Destimulating tariff system }\end{array}$ & $\begin{array}{l}\text { High share of fossil fuel } \\
\text { High } \mathrm{CO}_{2} \text { emission taxes } \\
\text { Some consumers refuse DH } \\
\text { High return temperature }\end{array}$ \\
\hline
\end{tabular}

As for tariffs, Kragujevac DH tariffs comparing with Narva DH tariffs are lower in Kragujevac when fixed tariff is applied and higher, when variable tariff is applied. It should be noted that Narva DH tariffs are the lowest in Estonia. If we compare the DH tariffs with local electricity prices, relation between heat and electricity prices is lower in Narva and this way of heat supply is more preferable, then electricity. This can be explained by the fact that Estonia's policy and support mechanisms are working well, which leads to system improvement.

\section{Discussion AND CONCluSions}

There are variable factors that affect DH improvement. During the implementation of DH, the determining factors are climate and types of buildings, but economic factors are more significant for DH improvement regulation. To assess the importance of these factors, factors affecting DH in Estonia and Serbia were compared. In addition, DH systems of Estonian Narva and Serbian Kragujevac were compared. The DH system in Narva has better operation efficiency parameters and environmental aspects, considering that Narva DH system is only supplied by an oil shale power plant.

Based on these analyses, the following recommendations can be made to improve DH systems in Serbia, including Kragujevac: 
- $\mathrm{CO}_{2}$ taxes will increase the use of renewable energy for heat production;

- Changes in the DH tariff system in Serbia can motivate both consumers and companies to increase energy efficiency;

- Obliging the DH operators to increase energy efficiency greatly affects system improvement;

- With the improvement of DH systems, the concept of DH regions can be implemented to give DH operators guarantees of base heat loads.

Strong and consistent government support, both through regulations and financial aid will lead to increased energy generation, distribution, and consumption efficiency in DH systems. In addition, the possibility of a wider use of geothermal energy for DH should be investigated. If these conditions are met, DH can significantly contribute to increasing the share of renewable energy and $\mathrm{CO}_{2}$ emission reduction in the Serbian energy sector.

\section{REFERENCES}

[1] Latosov E., Volkova A., Siirde A., Thalfeldt M. The Impact of Parallel Energy Consumption on the District Heating Networks. Environmental and Climate Technologies 2019:23:1-13. https://doi.org/10.2478/rtuect-2019-0001

[2] Lake A., Rezaie B., Beyerlein S. Review of district heating and cooling systems for a sustainable future. Renewable and Sustainable Energy Reviews 2017:67:417-25. https://doi.org/10.1016/j.rser.2016.09.061

[3] Pantaleo A. M., Giarola S., Bauen A., Shah N. Integration of biomass into urban energy systems for heat and power. Part II: Sensitivity assessment of main techno-economic factors. Energy Conversion Management 2014:83:362-376. https://doi.org/10.1016/j.enconman.2014.03.051

[4] Zach F., Erker S., Stoeglehner G. Factors influencing the environmental and economic feasibility of district heating systems - A perspective from integrated spatial and energy planning. Energy, Sustainability and Society 2019:9:25. https://doi.org/10.1186/s13705-019-0202-7

[5] Magnusson D. Swedish district heating - A system in stagnation: Current and future trends in the district heating sector. Energy Policy 2012:48:449-459. https://doi.org/10.1016/j.enpol.2012.05.047

[6] Latõšov E., Volkova A., Hlebnikov A., Siirde A. Technical improvement potential of large district heating network: Application to the Case of Tallinn, Estonia. Energy Procedia 2018:149:337-344.

https://doi.org/10.1016/i.egypro.2018.08.197

[7] Ziemele J., Cilinskis E., Blumberga D. Pathway and restriction in district heating systems development towards 4th generation district heating. Energy 2018:152:108-118. https://doi.org/10.1016/j.energy.2018.03.122

[8] Ziemele J., Vigants G., Vitolins V., Blumberga D., Veidenbergs I. District heating systems performance analyses. Heat energy tariff. Environmental and Climate Technologies 2014:13:32-43. https://doi.org/10.2478/rtuect-2014-0005

[9] Persson U., Werner S. District heating in sequential energy supply. Applied Energy 2012:95:123-131. https://doi.org/10.1016/j.apenergy.2012.02.021

[10] Werner S. International review of district heating and cooling. Energy 2017:137:617-631. https://doi.org/10.1016/j.energy.2017.04.045

[11] European Parliament Council of the European Union. Euroopa parlamendi ja nõukogu direktiiv (Directive of the European Parliament and of the Council) 2010/31/EL, 19. May 2010, hoonete energiatõhususe kohta (on the energy performance of buildings), 2010.

[12] Latõšov E., Volkova A., Siirde A., Kurnitski J., Thalfeldt M. Primary energy factor for district heating networks in European Union member states. Energy Procedia 2017:116:69-77. https://doi.org/10.1016/j.egypro.2017.05.056

[13] Latõšov E., Kurnitski J., Thalfeldt M., Volkova A. Primary Energy Factors for Different District Heating Networks: An Estonian Example. Energy Procedia 2016:96:674-684. https://doi.org/10.1016/j.egypro.2016.09.126

[14] Werner S. District heating and cooling in Sweden. Energy 2017:126:419-429. https://doi.org/10.1016/j.energy.2017.03.052

[15] Paiho S., Saastamoinen H. How to develop district heating in Finland? Energy Policy 2018:122:668-676. https://doi.org/10.1016/j.enpol.2018.08.025

[16] Volkova A., Latõšov E., Mašatin V., Siirde A. Development of a user-friendly mobile app for the national level promotion of the $4^{\text {th }}$ generation district heating. International Journal of Sustainable Energy Planning and Management 2019:20:21-36. https://doi.org/10.5278/ijsepm.2019.20.3

[17] Ziemele J., Gravelsins A., Blumberga A., Vigants G., Blumberga D. System dynamics model analysis of pathway to $4^{\text {th }}$ generation district heating in Latvia. Energy 2016:110:85-94. https://doi.org/10.1016/j.energy.2015.11.073 
[18] Kauko H., Kvalsvik K. H., Rohde D., Nord N., Utne Å. Dynamic modeling of local district heating grids with prosumers: A case study for Norway. Energy 2018:151:261-271. https://doi.org/10.1016/j.energy.2018.03.033

[19] Tuvikene T., Sgibnev W., Jovanovic D., Neugebauer D. (eds.). The thermodynamics of the social contract. Making infrastructures visible in the case of district heating in two towns in Serbia and Croatia n. d. In Post Socialist Urban Infrastructures. London: Routledge, 2019.

[20] Lukic N., Jurisevic N., Nikolic N., Gordic D. Specific heating consumption in the residential sector of Serbia Example of the city of Kragujevac. Energy and Buildings 2015:107:163-171. https://doi.org/10.1016/j.enbuild.2015.08.012

[21] Searle S. Y., Malins C. J. Waste and residue availability for advanced biofuel production in EU Member States. Biomass and Bioenergy 2016:89:2-10. https://doi.org/10.1016/j.biombioe.2016.01.008

[22] Verkerk P. J., Fitzgerald J. B, Datta P., Dees M., Hengeveld G. M., Lindner M., Zudin S. Spatial distribution of the potential forest biomass availability in Europe. Forest Ecosystems 2019:6:1-11. https://doi.org/10.1186/s40663-019$0163-5$

[23] Statistics Estonia. Eesti Statistika Kvartalikiri (Estonian Statistics Quarterly). 2/18. Q Bull Stat Est 2018:2.

[24] Eesti Taastuvenergia Koda. Taastuvenergia aastaraamat (Estonian Renewable Energy Chamber. Renewable Energy Yearbook). 2018.

[25] Ministry of Energy Republic of Serbia. Realization program of energy development strategy to 2015 for selective using of renewable energy sources till 2010, Strategic project. 2006.

[26] Fund E. D. Report on the preparation of the Heating Sector Action Plan of the Development Plan of the Energy Sector (in Estonian) 2016.

[27] Ministry of Economic Affairs and Communications (in Estonian). Estonian heat supply sector analysis 2013.

[28] Decree on Determining the Methodology for Determining the Price of the End Customer's Supply of Heat (Official Gazette 63/2015) n.d.

[29] ENERGETIKA D.O.O., n.d. [Online]. [Accessed 15.04.2020]. Available: http://energetika-kragujevac.com/

[30] Ministry of Mining and Energy. Energy sector development strategy of the Republic of Serbia for the period by 2025 with projections by 2030, 2016.

[31] KfW. Serbia: Rehabilitation of District Heating Systems in Novi Sad, Niš and Belgrade 2010. 